\title{
Resistance of Oppression in Exod 1-15 and Southern Africa: An Intersectional Perspective
}

\author{
NDIKHO MTSHISELWA (UNISA)
}

\begin{abstract}
The article investigates the oppression of people as well as its resistance in Exod 1-15 and Southern Africa, from an intersectional perspective. The Zimbabwean migrant women embody the intersectional struggles of the working-class people (class), women (gender) and immigrants (internationality) in Southern Africa. This scenario might have been the case in the world of the biblical texts. First, the study outlines the lived experiences of the Zimbabwean migrant women in South Africa in order to highlight the multi-layered and intersectional character of and the resistance of their oppression. Second, the essay probes the resistance of oppression in the Exodus narrative, with a specific interest in women. Third and lastly, the study shows how the intersectionality theory assists us in drawing a broader and relative depiction of the oppression of women in Exod 1-15 and in Southern Africa as well as the need to resist such oppression.
\end{abstract}

KEYWORDS: Oppression, Migration, Slavery, Resistance, Exodus, Women, Southern Africa, Intersectionality

\section{A INTRODUCTION}

In celebrating the pioneering work of David Tuesday Adamo in Old Testament studies within the framework of African biblical scholarship, the present article investigates the themes of oppression, migration, slavery and resistance in Exod 1-15 in light of the observable experiences of Zimbabwean migrant women in South Africa as well as from an intersectional perspective. Not only has Adamo engaged in a conceptual analysis in his African biblical scholarship, he also has employed African cultural hermeneutics to read texts such as Exod 15:26 in the African (Yoruba) context, thus, providing a timely illustration of a contextual reading of ancient biblical texts. ${ }^{1}$ Existing literature uncovers extensive research

* Submitted: 27/07/2021; peer-reviewed: 15/09/2021; accepted: 15/09/2021. Ndikho Mtshiselwa, "Resistance of Oppression in Exodus 1-15 and Southern Africa: An Intersectional Perspective," Old Testament Essays 34 no. 2 (2021): 503 - 529. DOI: https://doi.org/10.17159/2312-3621/2021/v34n2a12.

1 Adamo's works include David T. Adamo, "African Cultural Hermeneutics," in Vernacular Hermeneutics (ed. Rasiah S. Sugirtharajah; Sheffield: Sheffield Academic Press, 1999), 66-90; David T. Adamo, "The Task and Distinctiveness of African 
on the Exodus narrative that is foregrounded in various conceptual and methodological approaches which are contextually oriented. The contextual approaches that focus on the topic of women and Exodus include, but are not limited to, Marc M. Ela's "Black African perspective,"2 Madipoane Masenya's "perspective of (South) African women's experiences,"3 Juliana M. Claassens' "feminist approach," "Funlola Olojede's reading of the Exodus narratives in light of the "origin and migration narratives of the Yoruba" people ${ }^{5}$ and Nyasha Madzokere's "contextual reading" of the Exodus. ${ }^{6}$

Ela's question, "What is the message of the Book of Exodus today for millions of Africans in their religious, cultural, political and socio-economic situations?,"7 anticipates the liberation that an interaction between the Exodus narrative and the narratives of Africans could yield. For him, the prospects of liberating possibilities exist when the reader of the Exodus narrative "enter( $s)$ into solidarity with individuals and groups who are refused the dignity of being human, to denounce the abuses of established systems and to intervene to protect the weak." I am partly sceptical about reading the text "in solidarity" with people who are denied the dignity of being human. A plausible approach in my view is the one which is advocated by Gunther H. Wittenberg, namely, a reading that includes the active (and passive) participation of the ordinary oppressed

Biblical Hermeneutic(s)," Old Testament Essays 28/1 (2015): 31-52; David T. Adamo, "What Is African Biblical Hermeneutics?," Black Theology 13/1 (2015): 59-72; and David T. Adamo, “'I Am the LORD Your Healer' Exodus 15:26 (אנייהוהרפאך): Healing in the Old Testament and the African (Yoruba) Context," In die Skriflig 55/1 (2021): $1-8$.

2 Marc M. Ela, "A Black African Perspective: An African Reading of Exodus," in Voices from the Margin: Interpreting the Bible in the Third World (ed. Rasiah S. Sugirtharajah; Maryknoll: Orbis, 1991), 256-266.

${ }^{3}$ Madipoane Masenya (Ngwana' Mphahlele), "Liberation with Us? Re-reading the Book of Exodus in a Post-apartheid South Africa," Nigerian Journal of Biblical Studies 19/1 (2005): 1-14.

4 L. Juliana Claassens, "Resisting Dehumanization: Acts of Relational Care in Exodus 1-2 as Image of God's Liberating Presence," Scriptura: Journal for Contextual Hermeneutics in Southern Africa 105/1 (2010): 572-580; Juliana L. Claassens, Mourner, Mother, Midwife: Reimagining God's Delivering Presence in the Old Testament (Louisville: Westminster John Knox Press, 2012); L. Juliana Claassens, "Memories of Midwives," Journal of Biblical Literature 134/4 (2015): 877-881.

5 Funlola Olojede, "The Exodus and Identity Formation in View of the Yoruba Origin and Migration Narratives," Scriptura: Journal for Contextual Hermeneutics in Southern Africa 108/1 (2011): 342-356.

6 Nyasha Madzokere, “'Let My People Go!' A Contextual Reading of the Book of Exodus in Light of Political and Economic Crisis in Post-independent Zimbabwe," in Underdevelopment, Development and the Future of Africa (ed. Munyaradzi Mawere; Bamenda: Langaa Rpcig, 2017), 169-189.

7 Ela, "Black African Perspective," 256.

8 Ibid., 256. The italics are my insertion. 
people in contemporary communities. ${ }^{9}$ An entry into the discourse of resistance is located "within the context of historical struggles and conflicts" of ancient and contemporary communities. ${ }^{10}$ The question, "Liberation with us?," in Masenya's "Re-reading the Book of Exodus in a Post-apartheid South Africa," therefore comes as no surprise precisely because of the necessity to engage the ancient biblical texts alongside the oppressed Black masses and in light of their lived experiences. ${ }^{11}$ Considering the persistence of "gender inequality, racism, classism and xenophobia" in post-apartheid South Africa, Masenya's argument that the theological struggle for the liberation of the Black masses is far from being accomplished is justifiable. ${ }^{12}$ The image of a liberator God may be plausible when the interpretation of the Exodus narrative is seen to be addressing gender inequality, racism, classism and xenophobia. Partly consistent with Masenya's reading of the Exodus narrative is Claassens' study of the women in Exod 1-2. Following overtly in Elizabeth Johnson's ${ }^{13}$ footsteps, Claassens brings to light the hiddenness of the stories of the female characters in the midst of the broader Exodus story and the silence and ignorance of their voices in the Old Testament. ${ }^{14}$ That the Exodus narrative text reflects the marginalisation of women in the story of the oppression of the Israelites is an idea that is underresearched, which also seems to require further nuancing. In addition, and most significantly, Claassens argues that the story of the midwives in Exod 1:15-22 who out of fear of YHWH courageously outwitted the pharaoh and fostered new life "serves as a powerful symbol of ordinary people's ability to resist violence." 15 Furthermore, regarding the place of women in the Exodus narrative and in light of the origin and migration narratives of the Yoruba people, Olojede's contribution is significant. Olojede stresses that not only were the Israelites slaves in Egypt and a migrant people, ${ }^{16}$ their resistance of oppression and the liberation from bondage should be credited to YHWH. ${ }^{17}$ Although not explicitly stated by Olojede, it does seem that Exod 15 reflects women's involvement in the resistance of Israelites' bondage and the celebration of liberation. An investigation and further nuancing of this possibility is necessary, in my view.

9 Gunther H. Wittenberg, "Old Testament Theology: For Whom?," Semeia 73 (1996): 231.

10 Wittenberg, "Old Testament Theology," 221.

11 Masenya (Ngwana' Mphahlele), "Liberation with Us?," 1.

12 Ibid., 11.

13 Elizabeth A. Johnson, Friends of God and Prophets: A Feminist Theological Reading of the Communion of Saints (Sheffield: Continuum, 1999), 157.

14 Claassens, "Resisting Dehumanization," 579.

15 Claassens, Mourner, Mother, Midwife, 69; see also Claassens, "Memories of Midwives," 877.

16 Olojede, "Exodus and Identity Formation," 353.

17 Ibid., 350. 
Based on the existing literature relating to the Exodus narrative, there seems to be some room for further research that would underscore oppression and its resistance in relation to issues of class, gender, race and migration in the Hebrew Bible and the Southern African context. An interpretation of the Exodus narrative that considers the interconnected issues of class, gender and migration as embodied by the presence of women in Exod 1-15 is required. Interestingly, the realities of the Zimbabwean migrant women in South Africa seem to depict the quintessence of the interconnectedness of these issues, which may be sequentially gleaned in Exod 1-15. A question that emerges, therefore, is which methodological tool(s) can one utilise to arrive at a nuanced understanding of the oppression of women as well as its resistance in the Exodus narrative, which may be both significant and liberative to Zimbabwean migrant women in South Africa? Due to the interconnectedness of social categorisations such as race, class, gender and nationality that are associated with oppression in the Hebrew Bible and in light of the persistent oppression of black bodies in Southern Africa, I will employ intersectionality theory in this discussion. ${ }^{18}$ The hypothesis of the present study is that intersectionality theory provides helps in constructing a broader reading of the resistance of oppression in Exod 1-15 and Southern Africa, as experienced by women.

\section{B THE CASE OF ZIMBABWEAN MIGRANT WOMEN}

Worthy of investigation is the intersectionality of the experiences of oppression by the precarious black workers, black women and black Zimbabwean immigrants in South Africa. Taking my cue from Mtshiselwa's reading of the Old Testament texts in relation to the struggles of the working-class people in South Africa, I focus on the narrative of the Zimbabwean precarious black workers. ${ }^{19}$ The struggles of Zimbabwean migrant women are multi-layered and interconnected, hence my interest and the use of intersectionality.

The growing literature on migration and labour studies in Africa provides a window into the intersectionality of class, gender and internationality. Interesting is Zorodzai Dube's application of immigration theory derived from social sciences to demonstrate the interdisciplinary perspective in the study of

18 For a detailed definition and explanation of intersectionality theory, see Anna Carastathis, "The Concept of Intersectionality in Feminist Theory," Philosophy Compass 9/5 (2014): 304; Greta R. Bauer, "Incorporating Intersectionality Theory into Population Health Research Methodology: Challenges and the Potential to Advance Health Equity," Social Science \& Medicine 110/1 (2014): 10-17.

19 For an illustrative study of the South African working-class people and the bearing that the Pentateuchal texts have in the discourse of social injustice, see Ndikho Mtshiselwa, "Mind the Working-Class People! An African Reading of Leviticus 25:855 with Latino/a Critical Tools," Old Testament Essays 29/1 (2016a): 133-150. 
biblical narratives. ${ }^{20}$ The theorisation of migration emanates from the challenges related to political violence and socio-economic instability within various nation states, especially in the African continent. In explaining immigration theory Dube writes:

As theory, migration focuses on two fronts: firstly, the push factors which make individuals or family members forced to relocate to what they think is a safer location. For example, families or individuals living in war-torn areas are likely, if opportunity allows, to relocate to safer areas... Secondly, pull factor(s) focuses on exploring attractive aspects associated with destination that forces the individual or family to leave the place of birth. Not much difference exists between the two categories because push factors make individual to consider pull factors. However, pull factors are associated with people known as economic migrants who can compare their present status and possible opportunities in the place of destination. ${ }^{21}$

Said differently, the migration discourse focuses on issues that are associated with violence or economic challenges such as poverty in the country of birth namely the push factors, which push people to migrate to wealthier countries in search of better living conditions and on the issues that attract the migrants namely the pull factors. ${ }^{22}$ In what Mtshiselwa views as "altered democracy" under the then Mugabe's rule, brutal tyranny and/as imperialism in neo-colonial Zimbabwe ushered the oppression of the poor people, who resisted the élites imperialism of the Zimbabwe African National Union-Patriotic Front (ZanuPF). ${ }^{23}$ The violence against the oppressed people that was carried out by the army and police resulted in an economic downward spiral, which in turn caused many a person in Zimbabwe to leave the country in search of better living conditions in other nation states. ${ }^{24}$ For both Mbeki and Rugwiji, the political élites

20 Zorodzai Dube, “Jesus-The Immigrant Egyptian Jews in Matthew's Sondergut: A Migration Perspective," HTS Teologiese Studies/Theological Studies 75/4 (2019): 3; see also Zorodzai Dube, "The Ethiopian Eunuch in Transit: A Migrant Theoretical Perspective," HTS Teologiese Studies/Theological Studies 69/1 (2013): 1-7.

21 Dube, "Jesus," 2; cf. Dube, "Ethiopian Eunuch," 1-7.

22 Cf. Sally Peberdy and Jonathan Crush, "Trading Places: Cross-border Traders and the South African Informal Economy," SAMP Migration Policy Series 6 (Cape Town: Idasa/SAMP, 1998), 5; Rudo B. Gaidzanwa. Voting with Their Feet: Migrant Zimbabwean Nurses and Doctors in the Era of Structural Adjustment (No. 11; Uppsala: Nordiska Africaininstitute, 1999), 47; Zorodzai Dube, "Abraham and Jesus as Ancient Migrants: An African Migration Perspective," Perichoresis 14/1 (2016): 64.

23 Ndikho Mtshiselwa, "The Age of Reinvented Empire(s) in Africa in the Light of Persian Hegemonic Power: Reading the Books of Deuteronomy and Ezra-Nehemiah in the Context of Zimbabwe," Verbum et Ecclesia 36/1 (2015): 7.

24 Zoro Dube, "Speaking in Tongues as Emigration: A Social-psychological Understanding of Tongue Speaking Using Migration Theory," Scriptura: Journal for 
reinvented a socio-economic system of exploitation that was devised by the colonist. ${ }^{25}$ This reinvention is responsible for the economic inequality that turned many Zimbabweans into economic migrants. The Zanu-PF political élites are no exception, as the colonists, they (politicians and government officials alike) unfairly enrich themselves. Unlike Rugwiji, Dube makes a distinction between economic migrants and refugees based on the point of voluntarily leaving the country and being forced to leave the country of origin. ${ }^{26}$ I partly disagree with Dube because the political climate that imbues economic instability and struggle also forced the so-called economic migrants to leave Zimbabwe. When arriving in South Africa, many Zimbabwean migrants become precarious workers and are confronted by different categories and layers of oppression.

As Kalleberg has noted, precarious workers are people who are mostly employed in the informal sector. ${ }^{27}$ Hlatshwayo adds a helpful clarification to Kalleberg's definition noting that precarious work, particularly in South Africa, is "characterized by lack of legal protection, poor working conditions, and low wages." 28 A case study conducted by Hlatshwayo in Johannesburg uncovers the oppression experienced by many Zimbabwean precarious workers. He finds that undocumented migrants generally experience hardship when coming to South Africa, "but for women it is worse as they face sexual harassment, rape, and various forms of physical attacks." 29 Not only is gender-based violence perpetuated by other fellow Zimbabwean men on their way to South Africa, but also by South African men - including the police officials and other male civilians, on arrival in the country. According to Hlatshwayo, some of the participants in his case study shared experiences of being sexually harassed by South African policemen when caught with no legal documentation. The act would not be reported because of the fear of being deported to Zimbabwe. ${ }^{30}$ Whether the issue of sexual harassment of Zimbabwean women by South African police is true or not, especially since such case are not reported at the police station, the point that the lives of migrant women and their dignity matter

Contextual Hermeneutics in Southern Africa 110/1 (2010): 250; Mtshiselwa, "Reinvented Empire(s)," 6-8.

25 Moeletsi Mbeki, Architects of Poverty: Why African Capitalism Needs Changing (Johannesburg: Picador Africa, 2009), 10, 16, 106; Temba Rugwiji, "Appropriating Judean Post-exilic Literature in a Postcolonial Discourse: A Case for Zimbabwe" (PhD thesis, Pretoria, University of South Africa, 2013), 206-207.

26 Dube, "Speaking in Tongues," 251.

27 Arne L. Kalleberg, "Precarious Work, Insecure Workers: Employment Relations in Transition," American Sociological Review 74/1 (2009): 1-22.

28 Mondli Hlatshwayo, "The Trials and Tribulations of Zimbabwean Precarious Women Workers in Johannesburg: A Cry for Help?" Qualitative Sociology Review 15/1 (2019): 63.

29 Hlatshwayo, "Trials and Tribulations," 82.

30 Ibid., 82. 
requires some recognition on the part of all men, irrespective of nationality. In these cases, masculinity that is foregrounded in patriarchy and inhumane character and behaviours renders itself problematic. Local men often take advantage of black Zimbabwean women because of their vulnerability, thus proving that migration to South Africa comes with ill-treatment and compromise of the women's security.

Additionally, as Von Kitzing has argued, being underpaid and of lowincome makes black migrant Zimbabwean women more susceptible to structural and societal barriers and violence. ${ }^{31}$ The vulnerability of the migrant women caused by economic constraints often forces them to enter into intimate relationships as a form of survival. Kiwanuka asserts that "some of their intimate partners being aware of their vulnerable position manipulate, exploit and abuse these women." 32 It thus becomes clear that being underpaid and of low-income promotes unfavourable and harsh living conditions. It is therefore reasonable to point that because to some men the livelihood of female migrants from Zimbabwe does not matter, some resistance is a matter of necessity.

On arrival in Johannesburg, the first step by female migrants in pursuit of survival is to seek employment in order to improve their living conditions. Even though some of them are educated, their status as undocumented migrants implies that their only option is to engage in precarious work as domestic helps, cleaners and waitresses in private lodges or casual workers in restaurants and supermarkets. ${ }^{33}$ Furthermore, as Hlatshwayo has observed, "getting a job is usually accompanied by further difficulties such as low wages and poor working conditions." 34 No doubt, South African citizens from the rural parts of the country who migrate to the urban areas are also victims of poor working conditions and low wages. However, migration adversely affects migrant workers and women migrants from Zimbabwe more than their South African counterparts who are even affiliated to trade unions. Hlatshwayo's point that "the situation is worse for migrant workers, especially women" makes sense. ${ }^{35}$ Gender clearly plays a role, but male migrants also find themselves in precarious employment and are also oppressed. However, the situation for women is far too harmful.

31 Nora S. von Kitzing, "Gender-based Violence on Vulnerable Migrant Women in Peri-urban Johannesburg and How They Respond," Research Paper, University of the Witwatersrand, Johannesburg (2017): 1-24.

32 Monica Kiwanuka, "For Love or Survival: Migrant Women's Narratives of Survival and Intimate Partner Violence in Johannesburg," in Gender and Migration: Feminist Interventions (ed. Ingrid Palmary et al.; London: Zed Books, 2010), 164.

33 Dube, "Jesus," 2-3.

34 Hlatshwayo, "Trials and Tribulations," 82.

35 Ibid., 74. 
Thus, Hlatshwayo highlights the interconnectedness between gender and internationalism. Some of the participants ${ }^{36}$ in Hlatshwayo's case study in Johannesburg made the following comments: 1) "I worked as a domestic worker. There were no off days. I only had one Sunday per fortnight off," and 2) "No, we have never discussed it (long working hours with her employer) because that's what the employer wants us to do. At times one is scared to talk about such things, because the employer would feel that you are being smart." 37 These statements reveal not only that many female migrant workers from Zimbabwe are overloaded with work and work for very long hours (with no overtime pay), but also that their safety when coming from work in violent neighbourhoods is disregarded and compromised. In addition, the workers are afraid to resist the oppression by their employers, as "employers tend to blackmail migrant workers as soon as they start challenging their authority," 38 by threatening them with arrest and deportation because they do not have valid documentation to stay South Africa. This form of blackmail silences the oppressed workers and enables ill-treatment and oppression to persist among the women migrants in Johannesburg. The fear instilled in the oppressed workers necessitates the resisting of historic and persistent oppression of black bodies. Thus, the need to negotiate the restoration of the dignity and rights of the oppressed migrant women from Zimbabwe is undeniable. Furthermore, suffice to say, the blackmail is foregrounded on the issue that women are foreign nationals. They are illtreated not only because they are poor but also mostly because of their nationality. Xenophobia plays a part in the attitude towards these Zimbabwean migrant women as it foregrounds their ill-treatment. I am aware of the distinction often made between xenophobia and Afrophobia. However, my interest in the present study is on behaviours that depict "dislike," "hatred" and "fear" of foreigner nationals. It is rather difficult to accept the reality of Afrophobia, as many South African citizens have healthy relations with citizens from other African nation states.

Although Mutambara conducts a case study on the Zimbabwean migrant women in the province of KwaZulu Natal, her findings are both related to and distinct from those of Hlatshwayo. Mutambara's study provides the second illustration of the challenges experienced by the migrant women under investigation here. Mutambara's "study explores how xenophobic sentiments, gender-based violence and institutional violence affects migrant women more than local women due to how their oppression and violence is intertwined,"

36 Comments by the participants in Hlatshwayo's study were reported anonymously. 37 Hlatshwayo, "Trials and Tribulations," 78.

38 Ibid, 75; Mondli Hlatshwayo, "Xenophobia, Resilience, and Resistance of Immigrant Workers in South Africa: Collective and Individual Responses," in Just Work? Migrant Workers, Globalization and Resistance (ed. Aziz Choudry and Mondli Hlatshwayo; London: Pluto Publishers, 2016), 21-43. 
lending credence to Hlathwayo's findings. ${ }^{39}$ She highlights compound layers of oppression such as gender (being women), race (being black), legal status (being undocumented migrants), class (being economically disadvantaged), harsh urban lived experiences (including having no or minimal access to health care facilities and to service delivery), ${ }^{40}$ abusive relationships (gender-based violence mostly from their South African intimate male partners) and migration background that prompts xenophobic attacks from South African citizens. ${ }^{41}$ Her point establishes the intersectionality of the struggle of Zimbabwean migrant women in South Africa.

The situation of migrant workers on farms in the Limpopo Province presents a third illustration of the challenges and oppression experienced by Zimbabwean women in South Africa. Worthy of consideration is the case study conducted by Poul Wisborg, Ruth Hall, Shirhami Shirinda and Phillan Zamchiya on some of the farms in the province. ${ }^{42}$ As they also have observed, the political crisis and economic collapse in Zimbabwe led to the migration and displacement of women into Limpopo. Importantly, this labour and economic migration provided farming in the country with enormous benefits as the migrant women had skills necessary for the industry. ${ }^{43}$ However and sadly, the migration of these women appears to have compounded "already-existing market pressures towards flexible and insecure labour arrangements." 44 As aforementioned, migrants became integrated into precarious work that imbues insecure employment. Noteworthy is the discovery of a barely researched phenomenon of farms encapsulating the secondary economies in which, "non-employed dependants, some of them migrants, find incomes and a degree of protection, for example, problematically, as poorly paid nannies or sex workers or, more constructively,

39 Marcia Victoria Mutambara, "Xenophobia and Human Security: Gender-based Violence Experiences of Zimbabwean Women Working in the Informal Sector in Durban, KwaZulu-Natal" (PhD thesis, University of KwaZulu Natal, 2018), 180.

40 For further details on the challenges faced by Zimbabwean migrant women regarding the access to health facilities and resources, see Jonathan Crush and Godfrey Tawodzera, "Medical Xenophobia and Zimbabwean Migrant Access to Public Health Services in South Africa," Journal of Ethnic and Migration Studies 40/4 (2014): 655670; Helen L. Walls et al., "Understanding Healthcare and Population Mobility in Southern Africa: The Case of South Africa," South African Medical Journal 106/1 (2016): 14-15; Jonathan Crush and Godfrey Tawodzera, Living with Xenophobia: Zimbabwean Informal Enterprise in South Africa (No. 77; Southern African Migration Programme, 2017).

41 Mutambara, "Xenophobia and Human Security," 181.

42 Poul Wisborg et al., Farm Workers and Farm Dwellers in Limpopo, South Africa: Struggles over Tenure, Livelihoods and Justice (Cape Town: Institute for Poverty, Land and Agrarian Studies, 2013).

43 Wisborg et al., Farm Workers, 108.

44 Ibid., 108. 
as traders, craftspeople and service providers." 45 Migrant farm workers face multiplicity of health problems that closely connect the issues of health, economic well-being and livelihood. On this point, particularly the interconnectedness of health and insufficient financial resources, Wisborg et al. have this to say:

In general, salaries provide little opportunity to buy nutritious food, save, meet contingencies and seek medical attention. Some women workers on Timongo [farm in Limpopo] reported that their incomes are so low that they cannot afford the kinds of food they need to stay healthy, including milk products and vegetables. This has a serious impact on adults and children alike. HIV/AIDS also seriously harms human wellbeing and 'the bottom-line', as a farm owner said. Contraceptives and public information are provided but the social and material conditions appear to worsen the situation: patterns of casual and transactional sex are linked to split residence and to the desperate economic circumstances of some dwellers and workers, as witnessed throughout the region. ${ }^{46}$

The preceding comment agrees with Kiwanuka's observation that because they are aware of the vulnerable position of the Zimbabwean women, South African men often manipulate, exploit and abuse these women. ${ }^{47}$ Patterns of casual and transactional sex are occasioned by the economic vulnerability. As in other global communities, the issues of poverty, fatalism and dysfunctional behaviour are interwoven. ${ }^{48}$ The interconnectedness of the phenomena of gender, class and internationalism shed light on the problem teased out by Kiwanuka as well as by Wisborg et al. Being poor, a woman and a Zimbabwean migrant in South Africa results in a range of plights associated with livelihood and health.

As Wisborg et al. acknowledge, the Timongo farms are characterised by a white-controlled agricultural economy with black people being labour tenants and wage labourers. They are also characterised by historical white ownership of productive land - farms. ${ }^{49}$ The historical and persistent privilege of some white people regarding the issue of land ownership and farming is undeniable. It is thus reasonable to deduce that the unbearable conditions of the migrant women on the Limpopo farms are controlled by white owners. The owners seem to be ignorant of the point that the lives of the black migrant women from Zimbabwe matter. The issue of race thus may not be ruled out when it comes to the struggles

45 Ibid., 108.

46 Ibid., 110; see also FMSP (Forced Migration Studies Programme), Zimbabwean Migration into Southern Africa: New Trends and Responses (Johannesburg: FMSP, University of the Witwatersrand, 2009), 52-53.

47 Kiwanuka, "Love or Survival," 164.

48 Catherine Campbell, Letting Them Die: Why HIV/AIDS Intervention Programmes Fail (Bloomington: Indiana University Press, 2003).

49 Wisborg et al., Farm Workers, 49. 
of those women and it would be irrational to ignore the point that they are discriminated against and allowed to live under unsympathetic conditions, which partly strip them of their dignity.

The case of the Zimbabwean migrant women who work on a precarious basis in South Africa that is examined above contains depictions of an interconnected multi-layered oppression of people, which should be addressed in conversation with the biblical text. From the foregoing, it can be inferred without doubt that their lived experiences contain overlapping features of gender-based oppression, classism, racism and xenophobia. These features suppose and endorse the view that the lives of the migrant women from Zimbabwe ought to matter, especially their right to human dignity. Since historically the biblical texts have enjoyed an authoritative status in Southern Africa and across the globe, one wonders whether the foregoing case of the Zimbabwean migrant women would help us to advance an interpretation of the Exodus narrative that would provide helpful tips to the people of Southern Africa. Importantly, the present interpretation of the Exodus narrative, specifically, of Exod 1-15 in a way that significantly mirrors the multi-layered oppression of the Zimbabwean migrant women in South Africa would in turn help to highlight the features of resistance and liberation in the text.

\section{RESISTANCE OF OPPRESSION IN EXOD 1-15}

First, I do not intend to discuss in detail the Exodus narrative from a historicalliterary critical point of view, as that often distracts the reader's attention from the social issues reflected in the biblical narratives and subsequently hinders the experiences of the readers from interacting with the text. ${ }^{50}$ An enormous amount of research has been published on historical-literary critical readings of Exod 115. However, few remarks on the historical background of the Exodus story in its final form are warranted. Second, to engage with the biblical text meaningfully, it is important to make a statement about the identity of the people in Exod 1-15. Third, when considered from an intersectional perspective, the depiction of the oppression of women as well as the act of resistance in the Exodus story may help the modern reader to interact with the ancient text more closely.

\section{Historical background of the final form of the Exodus story}

That the Pentateuchal texts are a product of redaction over a period in differing contexts is a well-established point which enjoys consensus in Old Testament scholarship. Partly based on the noticeable repetition of words, ideas and phrases

50 Cf. Fernando F. Segovia, "Pedagogical Discourse and Practices in Cultural Studies: Towards a Contextual Biblical Pedagogy," in Teaching the Bible: The Discourse and Politics of Biblical Pedagogy (ed. Fernando F. Segovia and Mary Ann Tolbert; Maryknoll: Orbis Books, 1998), 118; Dube, "Abraham and Jesus," 66. 
as well as the various names of the Deity's mountain, among other features, it can be inferred without a doubt that Exod 1-15 underwent a process of literary transmission which produced the final form of the Exodus story. The transmission occurred in various stages. The story of Exodus in the form of an old verbal memory was initially engraved in the Israelite cultural memory and integrated into the first composition years after the period to which it is ascribed. ${ }^{51}$ Nadav Na'aman, among others, submits that "the Exodus story was composed for the first time in the seventh century BCE and the early edition reflects the historical experience of life in Judah under the dominion of the Assyrian empire." 52 Echoing Redford's assertion, Na'aman adds that the early version was edited extensively in the second half of the sixth century BCE by the editor of the Priestly School to reflect the "experience of the Jewish community in Egypt in the time of the exilic and early post-exilic period." 53 The latter was done by inserting into the Exodus story some elements of oppression borrowed from the reality of Egypt in the time of the Twenty-Sixth Dynasty $(664-525$ BCE $){ }^{54}$

Konrad Schmid submits that the author of the earlier story of the Exodus had no data by which he could substantially explain how the Israelites arrived and settled in Egypt and as a result left the question unanswered. ${ }^{55}$ Not only does

51 Nadav Na'aman, "The Exodus Story: Between Historical Memory and Historiographical Composition," Journal of Ancient Near Eastern Religions 11/1 (2011): 56.

52 Na'aman, "The Exodus Story," 67; see also Brevard S. Childs, "The Birth of Moses," Journal of Biblical Literature 84/2 (1965): 109-122; Simo Parpola, The Correspondence of Sargon II: Letter from Assyria and the West (Helsinki: University Press, 1987), 60-62; Tremper Longman III, Fictional Akkadian Autobiography: A Generic and Comparative Study (Winona Lake: Eisenbrauns, 1991), 53-60, 215-216; Simo Parpola, "The Construction of Dur-Šarrukin in the Assyrian Royal Correspondence," in Khorsabad, le palais de Sargon II, roi d'Assyrie (ed. Annie Caubet; Paris: La documentation Française, 1995), 47-77; Eckart Otto, "Mose und das Gesetz: Die Mose-Figur als Gegenentwurf politischer Theologie zur neuassyrischen Königstheologie im 7. Jh. v. Chr.," in Mose, Ägypten und das Alten Testament (ed. Eckart Otto; Stuttgarter Bibelstudien 189; Stuttgart: Katholosiches Bibelwerk, 2000), 51-67. Interestingly, because of the comparison of the legend of Moses' birth to that of the birth of Cyrus, Helena Zlotnick-Sivan dated Exod 2 to the post-exilic period, that is, to the Persian context. See "Moses the Persian? Exodus 2, the 'Other' and Biblical 'Mnemohistory'," Zeitschrift für die Alttestamentliche Wissenschaft 116/2 (2004): 189205. A late date for the first composition of the Exodus story is doubtful. Ascribing the final form to the post-exilic period is more reasonable.

53 Na'aman, "The Exodus Story," 67-68.

54 Donald B. Redford, "Observations on the Sojourn of the Bene-Israel," in Exodus: The Egyptian Evidence (ed. Ernest S. Frerichs and Leonard H. Lesko; Winona Lake: Eisenbrauns, 1997), 57-66.

55 Konrad Schmid, Genesis and the Moses Story: Israel's Dual Origins in the Hebrew Bible (Winona Lake: Esenbrauns, 2010), 122-126. 
the submission provide Na'aman some room to argue that the origin of the Israelites was in Canaan and not Egypt, it also leads him to consider locating the suffering alluded to in Exod 1-15 in the Canaanite context. That is, the bondage of the Israelites reflected in the text likely occurred in Canaan, instead of Egypt, because of the absence of data to verify the arrival and settlement of the Israelites in Egypt. I have cautious doubts about Na'aman's idea because of the absence of a compelling reason for the composer of the early version of the Exodus story and for the later redactors to avoid mentioning the bondage in Canaan.

The final form of the Exodus story bears features that are associated with scribal activity, which likely occurred in the exilic and post-exilic periods. First, noteworthy is the idea that the story of the birth of Sargon, king of Akkad-a story that was probably composed during the time of Sargon II (721-705 $\mathrm{BCE})^{56}$ - models the story of Moses' birth and upbringing in the Egyptian court. The idea drew a dating of the earlier story of Moses in Egypt to the seventh century BCE when the Assyrians were in power. ${ }^{57}$ The juxtaposition of the earlier story of Moses with the Patriarchal narratives is consistent with the idea of its elaboration in the late exilic and early Persian periods by editors of the Priestly source. ${ }^{58}$ As Na' aman has argued, the "Redactors who operated in this (exilic and post-exilic) period inserted all references to the Patriarchs into the story of the Exodus and the Deuteronomistic history." 59 In addition, "elements like suffering from bondage to foreign people, aspiration for freedom and strong opposition to slavery, and deep gratitude to the God who liberated the people of Israel from slavery and brought them out of Egypt" probably existed already "in its early stages of formation of the Exodus story." ${ }^{60}$ Brueggemann's point that the Judeans who were treated as slaves in Babylonia were equally treated as slaves by the Persian authorities in the post-exilic period, ${ }^{61}$ which is confirmed

56 Childs, "Birth of Moses," 109-122; Otto, "Mose und das Gesetz," 51-67; ZlotnickSivan, "Moses the Persian," 189-205.

57 Otto, "Mose und das Gesetz," 43-67; Felipe Blanco Wissmann, "Sargon, Mose und die Gegner Salomos: Zur Frage vor-neuassyrischer Ursprünge der Mose-Erzählung," Biblische Notizen 110/1 (2001): 42-54; Thomas C. Römer, "La construction d'une 'Vie de Moïse' dans la Bible Hébraïque et chez quelques auteurs Héllenistiques," Transversalités 85 (2003): 13-30.

58 Na'aman, "The Exodus Story," 65-66; Hoffman compares the early (pre-exilic) Exodus tradition with the late post-exilic (Persian) tradition. See Ya'ir Hoffman, "The Exodus-Tradition and Reality: The Status of the Exodus Tradition in Ancient Israel," in Jerusalem Studies in Egyptology (ed. Irene Shirun-Grumach; Ägypten und Altes Testament 40; Wiesbaden: Harrassowitz, 1998), 193-202.

59 Na'aman, "The Exodus Story," 41.

60 Ibid., 68.

61 Walter Brueggemann, Great Prayers of the Old Testament (Louisville: Westminster John Knox Press, 2008), 109; cf. Walter Brueggemann, Cadences of Home: Preaching among Exiles (Louisville: Westminster John Knox Press, 1997), 115; Emmanuel O. Usue, "Restoration or Desperation in Ezra and Nehemiah? Implications for Africa," 
by Neh 9:33, endorses the reworking and elaboration of the Exodus story in those periods. The re-conceptualisation of the idea of "slavery" and the theme of "deliverance from Egypt" in the exilic and post-exilic periods, with the deliberate use of the term "slaves," which speaks to the way the Judeans were treated in the workplace and subjected to "cheap labour" and "ill-treatment" (cf. Isa 52:5; Jer 51:6-7; Lam 3:1-9; Ps 137), makes some sense. ${ }^{62}$ The editing and finalisation of the Exodus story in the latter periods is in my view plausible.

However, the view that the Exodus story reflects the reality of Egypt at the time of the Nineteenth Dynasty (1295-1186 BCE) and the first half of the Twentieth (1186-1136 BCE) is worthy of a short remark. ${ }^{63}$ Although, "no evidence that might be connected - either directly or indirectly-to the Exodus story was ever detected in the Egyptian texts" and even if no archaeological data from Iron Age I sites associated with ancient Israel sheds light on the Exodus story, in my view the realities of these periods are alluring. ${ }^{64}$ It is not my intention to discuss in detail the history of the pastoral nomadic groups and sea people in the Nineteenth and Twentieth Dynasty in Canaan and Egypt. An enormous amount of research has been published on this subject. However, few remarks on the history of slaves in Egypt is warranted, since Egypt ruled Canaan for hundreds (about 350$)^{65}$ of years. The Egyptian royal inscriptions deemed to uncover some realities of the period of the Nineteenth-Twentieth Dynasties allude to wars in certain regions of Canaan. For instance, "The inscriptions of Sety and Ramesses mention a series of wars they conducted against the pastoralnomads (Shasu) located in Canaan."66 The wars were fought by prisoners from groups of people associated with ancient Israelites deported from the regions to Egypt.

Na'aman notes that, "with the rise of Merneptah (1213-1203 BCE) rebellion broke once again, and in one of his early years the new king conducted a campaign to Canaan, conquering Ashkelon, Gezer and Yeno' am and defeating a tribal group named 'Israel'." 67 That the Egyptian royal inscriptions relating to the wars against non-submissive population groups from Canaan with Egypt

Old Testament Essays 20/3 (2007): 843; Rugwiji, “Appropriating Judean Post-Exilic Literature," 46.

62 Rugwiji, “Appropriating Judean Post-Exilic Literature," 48-49.

63 For more on the Exodus, see Baruch Halpern, "The Exodus from Egypt, Myth or Reality?," in The Rise of Ancient Israel (Hershel Shanks; Washington: Biblical Archaeological Society, 1992), 86-117; Baruch Halpern, "The Exodus and the Israelite Historian," Eretz Israel 24 (1993): 89-96; James K. Hoffmeier, Israel in Egypt: The Evidence for the Authenticity of the Exodus Tradition (Oxford: Oxford University Press, 1997).

64 Na'aman, "The Exodus Story," 42.

65 Ibid., 64.

66 Ibid., 46

67 Ibid., 47. 
frequently mention the deportation of these groups to Egypt confirms the deportation of prisoners to Egypt, including the group named "Israel." 68 Mass deportations were not restricted to Canaan. They also took "place in all countries where the Pharaohs conducted military campaigns (Kush, Canaan, north and central Syria and Libya)." ${ }^{\prime 69}$ A passage from a papyrus of the Twentieth Dynasty illustrates the deportation of prisoners to Egypt. ${ }^{70}$ It reads: "I have brought back in great numbers those that my sword has spared, with their hands tied behind their backs before my horses, and their wives and children in the tens of thousands, and their livestock in hundreds of thousands."71 In addition, an inscription of Ramesses II from Abu Simbel depicts the deportation of people to Egypt. ${ }^{72}$ No doubt, Canaanite rulers also sent slaves to the Pharaoh as part of their regular tribute or as a gift. ${ }^{73}$ For example, the king of Gezer sent forty-six maidservants, five attendants and five guards, and the king of Jerusalem sent ten slaves, twenty-one young women and eighty prisoners. According to another letter, the Pharaoh sent an official to buy forty women for 160 diban $(1,600$ shekels) of silver, emphasising that the women must be "very beautiful, in whom there is no defect." 74

The present discussion therefore holds that people associated with Israelite identity entered Egypt for various reasons. In Redford's view, the prisoners of war, deportees and immigrants who entered Egypt during the New Kingdom were distributed to various localities and no evidence exists that they were able to keep their communal unity. ${ }^{75}$ For Na'aman, "the only ethnic group that settled in one place in great numbers is the Libyans who frequently migrated to Egypt through Egypt's poorly-guarded western front (unlike its well-guarded eastern front)." 76

The unresolved question of the historicity of the Exodus and wandering in the wilderness has led Na'aman to doubt the idea that Exod 1-15 mirrors the realities of the Israelites during the Late Bronze Age period. As an alternative, he cautiously hypothesises that the texts likely reflect the bondage and suffering

68 Ibid., 47.

69 Ibid., 48.

70 Antonio Loprieno, "Slaves," in The Egyptians (ed. Sergio Donadoni; Chicago: University of Chicago Press, 1997), 204-205.

71 See Na'aman, "The Exodus Story," 48-49.

72 Edda Bresciani, "Foreigners," The Egyptians (ed. Sergio Donadoni; Chicago: University of Chicago Press, 1997), 235.

73 Na'aman, "The Exodus Story," 48.

74 For translation of the three letters, see William L. Moran, The Amarna Letters (Baltimore: Johns Hopkins University Press, 1992), 315, 331, 366. For a discussion of their contents, see Nadav Na'aman, "Dispatching Canaanite Maidservants to the Pharaoh," Ancient Near Eastern Studies 39/1 (2002): 76-82.

75 Redford, "Observations on the Sojourn," 57-66.

76 Na'aman, "The Exodus Story," 49. 
of a group associated with the Israelites during the Nineteenth and Twentieth Dynasty, when the people in Canaan were subjected to the oppressive rule of the Egyptians. ${ }^{77}$ However, his hypothesis seems doubtful because of the alluring evidence of the prisoners of war, deportees and immigrants who historically entered or were deported to Egypt. I find no evidence of such groups leaving Egypt at the later periods. It is therefore possible that Exod 1-15 reflects a historic memory of the preceding groups and/as categories of people who were probably in Egypt and were subjected to the oppressive rule of the Pharaohs. Given the conclusive point that based on later memory that Exod 1-15 was composed for the first time around the seventh century BCE and underwent revisions and some adaptations in the exilic and post-exilic periods, it may be inferred that the text is about migrants, prisoners of war and slaves in different contexts. Exodus 1-15 reflects the memory of the preceding people who historically entered Egypt due to various reasons in differing periods.

\section{Oppression and resistance in Exod 1-15}

A pertinent question to pose is: who were the oppressed people in the final form of the Exodus story and what form of oppression did they experience? Asked differently, which oppressed people does the Exodus story reflect and what form of oppression can we glean from the story? The question is about the identity of the oppressed people in the text as well as the kind of oppression they experienced. The fact that Exod 1-15 has often been read as a text, which articulates the liberation of the Israelites (socio-economic freedom) is far from negating the expression of oppression and its resistance.

1a Exodus narrative and slavery - harsh labour

The Exodus story presents allusions to the liberation of the Israelites, the nonEgyptians, from slavery, that is, hard labour. The allusions presuppose adverse and oppressive conditions which stripped away the right to live and the dignity of "the people of the land" (Exod 5:5). Exodus 1:10 relates a statement by the Pharaoh: "Come, let us deal shrewdly with them, lest they multiply, and, if war befall us, they join our enemies and fight against us and escape from the land." The fear of the non-Egyptians-the Israelites-becomes evident and it led to their oppression. The statement is followed by the confirmation of the existing oppression of the Israelites with the reference to forced labour (heavy burdens, RSV). Exodus 1:12 responds to verses 9-10, which is linked by verse 11 with the word "oppressed." The "slave masters" implemented the instruction to oppress the Israelites (Exod 1:11). Noteworthy, though, are the statements: "But the more they were oppressed, the more they multiplied and the more they spread abroad. And the Egyptians were in dread of the people of Israel" (Exod 1:12). Exodus 1:13-14 confirms that the Egyptians made the lives of the Israelites bitter with harsh labour "in mortar and brick, and in all kinds of work in the field." The

77 Ibid., 39-69. 
author of Exodus 3:7 picks up the misery of the Israelites, but (probably the editor) introduces the phrase, "slave drivers," a term different from "slave masters" used in Exod 1:11, thus indicating different pens. The phrase "hand of the Egyptians" indicates that the Israelites were not only oppressed by the Pharaoh of Egypt, but also by other Egyptians. The texts depict different authors and various levels of class and social status (i.e., the king, slave masters, slave drivers, and those identified as "hand of Egyptians") among the Egyptians that oppressed the Israelites. Exodus 3:9 is a repetition of Exod 3:7, which likely hints at different scribes. These texts allude to "crying," however, verse 9 specifically employs the words "oppressing" (Exod 1:11-12) instead of "misery" and "suffering" in Egypt. Exodus 5:3 notes some resistance to the oppression of "the people of the land." Moses asks the Pharaoh to allow the people to embark on a three days' journey to the wilderness to offer sacrifice to YHWH. The request suggests resistance aimed at advancing the liberation of the Israelites from Egypt and enhancing YHWH's covenantal relationship with the Israelites. However, a contestation of this resistance is denoted in Exod 5:5-7, where Pharaoh rejects Moses' request and gives the instruction that the oppression should be uninterrupted. Verse 5 shows that the Pharaoh is disturbed by the numeric growth of the Israelites and the seeming providence of rest for them, whilst verses 6-7 allude to the Pharaoh's instructions to the taskmasters and the foremen: "You shall no longer give the people straw to make bricks, as heretofore; let them go and gather straw for themselves." Could the move be regarded as a sign of xenophobia?

Exodus 5:6 continues with the presentation of the oppression of the Israelites-non-Egyptians-in Egypt. This is however uniquely cast apparently by a different scribe. "Slave drivers" are mentioned alongside the new word introduced in the Exodus narrative, namely, "overseers," who were instructed by Pharaoh to ensure that the Israelites persistently carry out the harsh labour (Exod $5: 6)$. This probably reflects the work of a different scribe from the one who used the phrase, "slave drivers." The "overseers" are the Israelites (Exod 5:15). In Exodus 5:9, the scribe accounts for the instruction that the Israelites must work hard under intensified labour conditions. A point worthy of note is one that often reflects the view of the oppressor when intensifying hardship, that is, the working-class or slaves are lazy when they resist oppression. The Pharaoh sees the Israelites as lazy people (Exod 5:8, 17).

In addition, various class levels among the Israelites are identifiable in Exod 5:6, 21. Whilst some Israelites work under harsh conditions as slaves, some serve as the overseers of the slaves who worked for the Egyptian Pharaoh. It comes as no surprise that the Israelite "overseers" had access to the Pharaoh (Exod 5:15), as they subsequently became active participants in the system that oppressed the Israelites. However, the "overseers" appear to be in solidarity with the slaves who engage in the tasks. On behalf of the group of labourers, they complain to the Pharaoh and to Moses (Exod 5:6-8, 21). They accuse Moses of 
being responsible for the intensification of harsh labour and making them obnoxious to Pharaoh (Exod 5:21). Thus, some slaves held a privileged position with the slave master, while others in the field were in a disadvantaged socioeconomic location. The privileged ones were treated with kindness by the slave master compared to their counterparts who are beaten by the Egyptians (Exod 5:15). Slavery in the Exodus narrative connotes the presence of slaves who work under harsh conditions. As will be shown shortly, the problem of harsh labour includes women. Men do not exist alone without women, especially when it may be confirmed from the memory of the composer of the Exodus story that atheist women were part of the historic deportation to Egypt.

\section{2a Exodus narrative and economic prosperity}

The Exodus story features the idea of economic liberation in the form of land ownership and economic prosperity (Exod 3:8; recaptured in v.17). YHWH promises the Israelites a land flowing with milk and honey. Thus it is clear that the Exodus and liberation would be incomplete without the possession of the means of production and economic welfare. Interestingly, the Priestly editor of Exod 6:2-8 presents the juxtaposition of the Exodus narrative and the patriarchs with the issue of economic prosperity at the centre. The introduction of YHWH to Moses echoes the memory of the covenant established between YHWH and the patriarchs namely Abraham, Isaac and Jacob (Exod 6:2-3). The covenant included the "land of Canaan, the land in which they dwelt as sojourners" (Exod 6:4). The liberation of the Israelites from the Egyptian bondage is interwoven with religious undertones as well as economic freedom. YHWHW says, "And I will bring you into the land which I swore to give to Abraham, to Isaac, and to Jacob; I will give it to you for a possession" (Exod 6:8). The statement contrasts with verse 4, a text insinuating that the land of Canaan is the "land in which they dwelt as sojourners." On the one hand, verse 8 presents the land as a promised possession. On the other hand, it seems that at some point in history the patriarchs and their families possessed and dwelt in the Promised Land as "sojourners."78 These texts stand in contrast and thus reflect the possibility of different authors and different contestations. One may also resolve this apparent contradiction by viewing verse 8 as a later insertion that builds on verse 4 to suggest that the Israelites in Egypt would be made to inherit the land that was once occupied by the patriarchs. That the Promised Land was presumably occupied by the patriarchs is beside the point here. Importantly, the text in part reflects economic distress as the Israelite are cast as being distant from economic prosperity.

The economic status of the Israelites in Egypt may be contested. The idea that the Israelites were slaves in Egypt under adverse conditions requires an

78 For a discussion of the Promised Land, see Ndikho Mtshiselwa, "Who Possessed the Promised Land? Scribal Scholarship in the Formation of Patriarchal Narrative(s) and the Holiness Code," Semitica 58/1 (2016b): 63-78. 
explanation as the texts suggest that there were some contestations. As aforementioned, the texts of Exod 1:11-12; 3:7, 9 presuppose economic realities characterised by "misery" and "suffering" as well as "crying." These words insinuate a situation of economic adversity. However, Exod 12 provides a different depiction of the Israelites in Egypt. That Exod 12:1-4 refers to the Israelites "slaughtering" lambs, suggest that some of "the people of the land" owned livestock. The statement, "take your flocks and herds" in Exod 12:32, 38 presupposes that though designated as slaves working under harsh conditions, some Israelites were farmers and owned livestock. Owning livestock presumes a level of economic privilege. Of course, the livestock grazed on some land. However, there is no evidence that some Israelites owned productive land in Egypt during the epoch of slavery. Exodus 12:1-4; 12:32, 38 hint at a different view from the texts that present the Israelites as suffering in Egypt. However, at their Exodus, the Israelites were given articles of silver and gold as well as clothes by the Egyptians (Exod 12:35-36), thus indicating economic dependency on the Egyptians. In other words, some Israelites enjoyed a degree of economic privilege, whilst many others lived under harsh economic conditions. These varied depictions denote some contestations among the scribes and possibly reflect different economic levels among the Israelites not only in their historic memory but also during the periods of composition and redaction.

A question to ask is: Does the text of Exod 1-15 depict women living under harsh economic conditions?

\section{3a Exodus narrative and women}

Exodus 1-15 explicitly mentions women-the midwives, the Pharaoh's daughter and her maidservants, Moses' mother and sister, the daughters of the priest of Midian, and Miriam, the prophetess as well as women singing with Miriam. Other women may also be unmentioned and present in the socioeconomic realities reflected in the Exodus narrative.

In Exod 1:15-16, the Pharaoh instructs the midwives, whose names were Shiph'rah and Pu'ah, to carry out his genocidal decision of killing the Hebrew boy children. Since his instruction contains elements of "dislike," "hatred," and "fear" of foreigner nationals, it is reasonable to deduce that the Pharaoh had called for a xenophobic genocide. Since the Israelites were growing in number, the Pharaoh feared that if war befell the Egyptians, they (the Israelites) would join the enemies and fight against them and escape from the land (Exod 1:9-10). The command, "you shall kill him," which is framed by a conditional formulation, "When you serve as midwife to the Hebrew women, and see them upon the birthstool, if it is a son ... but if it is a daughter, she shall live," depicts the abuse of power on the part of the male figure in authority namely the Pharaoh (Exod 1:15; cf. v. 22). The Pharaoh's instruction is an instance in which a male figure sought to bully women, a tendency that is common in patriarchal biblical texts. Suffice to note, the killing of the Hebrew boy children also meant pain for 
the Hebrew mothers. No mother would kindly accept the death of her child. Had the midwives succumbed to the instruction of the oppressive and evil Pharaoh, pain would have been imposed on them. However, as Oduyoye has argued, the fact that the midwives refused to be co-opted by the oppressor exemplifies the resistance of the xenophobic ill-treatment of the Hebrew women and the genocidal attempt of the Pharaoh. ${ }^{79}$ Due to their "fear of God," 80 the Hebrew midwives disobeyed the Pharaoh by distancing themselves from the instruction to kill the infant boys, thus, preserving the lives of the children. In this case, the scribe cast the women in a positive and constructive light. They resisted injustice and ill-treatment. I therefore concur with Claassens who argues that the memory of the midwives serves "as a powerful symbol of ordinary people's ability to resist violence." 81

Following the resistance of the genocidal attempts and xenophobic commands by the midwives, the Pharaoh unrelentingly commanded the xenophobic attacks of the Hebrew boys, and by default ill-treated the Hebrew women (Exod 1:22). In this case, all the Egyptians were subject to the instruction including the Pharaoh's daughter. No doubt, this case shows the subjection of women, irrespective of family ties, to the authority of an oppressive male figure. However, and more importantly, the text depicts an "image of the Egyptian princess who resisted the genocidal inclinations of her father" and acted with compassion by saving a life when she heard the cry of the infant boy (Exod 2:6, 8-9). Although it is evident that the princess resisted her father's command to kill the infant boy, an act that is commendable, the point that she owned female slaves (Exod 2:5) ${ }^{82}$ and instructed them to perform tasks that violated the Pharaoh's instructions is worthy of note. When Exod 2:5, with its allusion to female slaves or maidens, is read in conjunction with verses 8-9, specifically, in light of the reference to an expressed conditional promise, "and I will give you your wages" (v.9), it may be deduced that some Hebrew women performed some activities for payment. Moreover, one should not overlook the idea that some of the maidservants in Egypt, that is, in the final form of the story, were Israelites. The idea is unsurprising because the historic memory that likely mirrors the realities of Nineteenth and Twentieth Dynasty period (1295-1136 BCE) shows the deportation of maidservants to Egypt, which is linked to the Israelites. It

79 Mercy A. Oduyoye, Beads and Strands: Reflections of an African Woman on Christianity in Africa (Maryknoll: Orbis Books, 2002), 6; see also Theresa Okure, "Women in the Bible," in With Passion and Compassion: Third World Women Doing Theology (ed. Virginia Fabella and Mercy A. Oduyoye; Maryknoll: Orbis Press, 1988), 53; Claassens, "Memories of Midwives," 878.

80 The verses of Exodus 1:17, 21 specifically refer to the fear of God, a feature associated with the pre-Priestly writers.

81 Claassens, Mourner, Mother, Midwife, 69; see also Claassens, "Memories of Midwives," 877.

82 Whereas the New International Version identifies the women as "female slave," the Revised Standard Version refers to them as "maidens." 
seems that the domestic workers of the Pharaoh's daughter were compensated for their labour. However, one cannot ascertain whether they were underpaid or not due to lack of evidence. It is possible, though, that some Israelite women worked in the palace and were treated well. However, based on the text of Exod $1-15$, the existence of maidservants who worked outside the palace of the Pharaoh or who were underpaid for their task can neither be confirmed nor denied.

Since the stories of women are rarely articulated in an extensive and convincing manner in both biblical and extra-biblical materials, their assertion and investigation are necessary in Old Testament scholarship. Imagining that the Exodus story partly mirrors the realities of the Nineteenth and Twentieth Dynasty of the Egyptian Pharaohs, as well as the various contexts: the pre-exilic (around the seventh century BCE); exilic period; and the post-exilic period, it is fitting to give attention to the historic memory against which the story was composed. On the other hand, it is difficult to imagine that women were not part of the slaves and migrants that historically entered and lived in Egypt or part of the oppressed people from the later periods in Exod 1-15. Similar to the situation of the Zimbabwean migrant women in South Africa, the text reflects the interconnectedness of the struggles of women. Issues of nationality, gender and class may be read as interwoven in the Exodus narrative.

4a Navigating the resistance of oppression

Consistent with the idea of resisting oppression in this essay and worthy of consideration is the contribution by Funlola Olojede, which in my view equally asserts the struggle of women that is foreshadowed in Exod 1-15. However, my interest at this point lies in the question, to whom should the resistance be ascribed to and what type of resistance can we detect from the text? It is indisputable that YHWH is responsible for the resistance of oppression both in the biblical texts and in historic memories that are barely inscribed in extrabiblical materials as well as in modern stories of human beings. Upon hearing the cry of the Israelites, YHWH intervened. YHWH was responsible for the resistance and sequential revolution. The participation of Moses and other humans brought the idea into reality. I can relate to Olojede's view that YHWH was responsible for the liberation of the Israelites in the Exodus story. A compelling and plausible argument is that Israel's identity is rooted in YHWH, the God of Israel and that without this deity there was no crossing of the Red Sea neither was there liberation from the Egyptian bondage. ${ }^{83}$ Echoing Gowan's view, Olojede opines that the non-mention of God in Exod 1-2 does not imply the disregard of the deity or the assumption of deity's absence as "God is

83 Olojede, "Exodus and Identity Formation," 352. 
depicted as the dominant figure" and is both vocal and active throughout the book. ${ }^{84}$

The point that the Israelite men participated in the resistance of oppression cannot be overstressed. The role played by Moses and Aaron is undeniable. However, to focus here is the participation of women in the resistance of oppression. From the foregoing, it can be inferred without doubt that the Hebrew midwives, the Egyptian princess, the maidservants of the Pharaoh's daughter, the prophetess Miriam as well as women singing with Miriam, participated in YHWH's act of liberating the Israelites. One may also imagine that other unmentioned or silenced women in the narrative form part of the liberation of the Israelites and mirror resistance of oppression.

An interaction with the biblical text, on the part of the modern reader, specifically considering the realities of the Zimbabwean migrant women, also indicates the need for further research. Could the cry of the people constitute a form of resistance? In my view, the cry of human beings constitutes an integral part of the resistance of oppression. The resistance is carried out by YHWH, since it was YHWH who intervened and defeated the Pharaoh, of course, with the participation of some humans. It is without doubt that YHWH responded to the cry of the Israelites: "Although the people were armed for battle when leaving Egypt, they did not use those arms - it was Yahweh who fought for his people." 85 The cry of the Israelites in the Exodus story calls to mind the South African song, Thula mntanami: ${ }^{86}$

1. Thula mntanami [be still my child]

2. Wen'ukhalelani [why do you cry]?

3. Zizojik'izinto [things will turn around]

4. Thula mntanami [be still my child], Wen'ukhalelani [why do you cry]?

5. Isikhalo somntwana sihoye [a child's cry must be tended to]

6. Thula mntanami [be still my child], Wen'ukhalelani [why do you cry]?

The song is a call to resist the oppression in the Southern African context. A cry and a song in South Africa, as well as in many African countries form an integral

84 Ibid., 352; also see Donald E. Gowan, Theology in Exodus: Biblical Theology in the Form of a Commentary (Louisville: John Knox Press, 1994), 3.

85 Olojede, "Exodus and Identity Formation," 353.

86 Milisuthando Bongela, "The Quest for Intonga Yam," Mail \& Guardian n.p. [cited 8 July 2021]. Online: https://mg.co.za/article/2018-10-19-00-the-quest-for-intongayam/; Cf. Various Artists, “Zizojik'izinto," YouTube, n.p. [cited 8 July 2021]. Online: https://www.youtube.com/watch?v=YLEySly3SxM. The preceding version includes the line, iANC izobusa ungakhali mntanami [ANC will reign, refrain from crying my child]. 
part of the resistance of the oppressed people. The song has been adapted and appropriated in various circumstances and contexts of struggle relating to violence and the abuse of children and women, gender-based ill-treatment and violence, harsh labour of women, absence of economic livelihood and prosperity.

\section{CONCLUSION}

A fitting conclusion to the study, which is inspired by Adamo's pioneering work finds its expression in Joachim Eck's article titled, "Divine Strategies against Abuse of Power in the Opening of the Book of Isaiah and the Exodus Story: Some Aspects Where Micah Is not Similar to Isaiah."87 The Exodus narrative exhibits a divine strategy, that is, resistance, set against oppression. Based on its final form, we may argue with some degree of caution that some parts of the text of Exod 1-15 mirror realities of oppression and its resistance which are associated with the historic memory of the Exodus story and context(s) linked to stages of its formulation (composition and redaction). The oppression of women reflects multi-layered and interconnected categories that are teased out with the help of the intersectionality theories. The expressions of oppression and resistance overlap. The point that Exod 1-15 reflects both oppression and resistance is thus plausible. The study shows how the intersectionality theory assist us to probe the oppression of women in Exod 1-15 in light of the multilayered oppression of Zimbabwean migrant women in Southern Africa as well as its possible resistance. The plight of the migrant Zimbabwean women could be taken to the level where the women resist oppression beyond simply crying to God. However, limited by the scope of the present study, the issue of how other stakeholders may help to ease the plight of the oppressed women besides understanding its intersectional nature is reserved for further research.

\section{E BIBLIOGRAPHY}

Adamo, David T. "African Cultural Hermeneutics." Pages 66-90 in Vernacular Hermeneutics. Edited by Rasiah S. Sugirtharajah. Sheffield: Sheffield Academic Press, 1999. "The Task and Distinctiveness of African Biblical Hermeneutic(s)." Old Testament Essays 28/1 (2015a): 31-52.

. "What Is African Biblical Hermeneutics?" Black Theology 13/1 (2015b): 5972.

. "II Am the LORD Your Healer' Exodus 15:26 (אנייהוהרפאך): Healing in the (Old Testament and the African (Yoruba) Context." In die Skriflig 55/1 (2021): $1-8$.

87 Joachim Eck, "Divine Strategies against Abuse of Power in the Opening of the Book of Isaiah and the Exodus Story: Some Aspects Where Micah Is not Similar to Isaiah," Zeitschrift für die Alttestamentliche Wissenschaft 130/1 (2018): 4-25. 
Bauer, Greta R. "Incorporating Intersectionality Theory into Population Health Research Methodology: Challenges and the Potential to Advance Health Equity." Social Science \& Medicine 110/1 (2014): 10-17.

Blanco Wissmann, Felipe. "Sargon, Mose und die Gegner Salomos: Zur Frage vorneuassyrischer Ursprünge der Mose-Erzählung.” Biblische Notizen 110/1 (2001): $42-54$.

Bongela, Milisuthando. “The Quest for Intonga Yam.” Mail \& Guardian n.p. [Cited 8 July 2021]. Online: https://mg.co.za/article/2018-10-19-00-the-quest-forintonga-yam/.

Bresciani, Edda. "Foreigners." Pages 221-253 in The Egyptians. Edited by Sergio Donadoni. Chicago: University of Chicago Press, 1997.

Brueggemann, Walter. Cadences of Home: Preaching among Exiles. Louisville: Westminster John Knox Press, 1997.

. Great Prayers of the Old Testament. Louisville: Westminster John Knox Press, 2008.

Campbell, Catherine. Letting Them Die: Why HIV/AIDS Intervention Programmes Fail. Bloomington: Indiana University Press, 2003.

Carastathis, Anna. "The Concept of Intersectionality in Feminist Theory." Philosophy Compass 9/5 (2014): 304-314.

Childs, Brevard S. "The Birth of Moses." Journal of Biblical Literature 84/2 (1965): 109-122.

Claassens, Juliana M. "Resisting Dehumanization: Acts of Relational Care in Exodus 1-2 as Image of God's Liberating Presence." Scriptura: Journal for Contextual Hermeneutics in Southern Africa 105/1 (2010): 572-580.

. Mourner, Mother, Midwife: Reimagining God's Delivering Presence in the Old Testament. Louisville: Westminster John Knox Press, 2012.

. "Memories of Midwives." Journal of Biblical Literature 134/4 (2015): 877881.

Crush, Jonathan and Godfrey Tawodzera. "Medical Xenophobia and Zimbabwean Migrant Access to Public Health Services in South Africa." Journal of Ethnic and Migration Studies 40/4 (2014): 655-670.

. Living with Xenophobia: Zimbabwean Informal Enterprise in South Africa.

No. 77. Southern African Migration Programme, 2017.

Dube, Zoro. "Speaking in Tongues as Emigration: A Social-psychological Understanding of Tongue Speaking Using Migration Theory." Scriptura: Journal for Contextual Hermeneutics in Southern Africa 110/1 (2010): 249-258.

. "The Ethiopian Eunuch in Transit: A Migrant Theoretical Perspective." HTS Teologiese Studies/Theological Studies 69/1 (2013): 1-7. . "Abraham and Jesus as Ancient Migrants: An African Migration Perspective." Perichoresis 14/1 (2016): 63-75.

. 'Jesus - The Immigrant Egyptian Jews in Matthew's Sondergut: A Migration Perspective.” HTS Teologiese Studies/Theological Studies 75/4 (2019): 1-5. 
Eck, Joachim. "Divine Strategies against Abuse of Power in the Opening of the Book of Isaiah and the Exodus Story: Some Aspects Where Micah Is not Similar to Isaiah." Zeitschrift für die Alttestamentliche Wissenschaft 130/1 (2018): 4-25.

Ela, Marc M. "A Black African Perspective: An African Reading of Exodus." Pages 256-266 in Voices from the Margin: Interpreting the Bible in the Third World. Edited by Rasiah S. Sugirtharajah. Maryknoll: Orbis, 1991.

FMSP (Forced Migration Studies Programme). Zimbabwean Migration into Southern Africa: New Trends and Responses. Johannesburg: FMSP, University of the Witwatersrand, 2009.

Gaidzanwa, Rudo B. Voting with Their Feet: Migrant Zimbabwean Nurses and Doctors in the Era of Structural Adjustment. No. 11. Uppsala: Nordiska Africaininstitute, 1999.

Gowan, Donald E. Theology in Exodus: Biblical Theology in the Form of a Commentary Louisville: John Knox Press, 1994.

Halpern, Baruch. "The Exodus from Egypt, Myth or Reality?" Pages 86-117 in The Rise of Ancient Israel. Hershel Shanks. Washington: Biblical Archaeological Society, 1992.

. "The Exodus and the Israelite Historian.” Eretz Israel 24 (1993): 89-96.

Hlatshwayo, Mondli. "Xenophobia, Resilience, and Resistance of Immigrant Workers in South Africa: Collective and Individual Responses." Pages 21-43 in Just Work? Migrant Workers, Globalization and Resistance. Edited by Aziz Choudry and Mondli Hlatshwayo. London: Pluto Publishers, 2016.

. "The Trials and Tribulations of Zimbabwean Precarious Women Workers in Johannesburg: A Cry for Help?" Qualitative Sociology Review 15/1 (2019): 6285.

Hoffman, Ya'ir. "The Exodus-Tradition and Reality: The Status of the Exodus Tradition in Ancient Israel." Pages 193-202 in Jerusalem Studies in Egyptology. Edited by Irene Shirun-Grumach. Ägypten und Altes Testament 40. Wiesbaden: Harrassowitz, 1998.

Hoffmeier, James K. Israel in Egypt: The Evidence for the Authenticity of the Exodus Tradition. New York and Oxford: Oxford University Press, 1997.

Johnson, Elizabeth A. Friends of God and Prophets: A Feminist Theological Reading of the Communion of Saints. Sheffield: Continuum, 1999.

Kalleberg, Arne L. "Precarious Work, Insecure Workers: Employment Relations in Transition." American Sociological Review 74/1 (2009): 1-22.

Kiwanuka, Monica. "For Love or Survival: Migrant Women's Narratives of Survival and Intimate Partner Violence in Johannesburg." Pages 141-162 in Gender and migration: Feminist Interventions. Edited by Ingrid Palmary et al. London: Zed Books, 2010.

Longman III, Tremper. Fictional Akkadian Autobiography: A Generic and Comparative Study. Winona Lake: Eisenbrauns, 1991.

Loprieno, Antonio. "Slaves." Pages 185-219 in The Egyptians. Edited by Sergio Donadoni. Chicago: University of Chicago Press, 1997. 
Masenya (Ngwana' Mphahlele), Madipoane. "Liberation with Us? Re-reading the Book of Exodus in a Post-apartheid South Africa." Nigerian Journal of Biblical Studies 19/1 (2005): 1-14.

Moran, William L. The Amarna Letters. Baltimore: Johns Hopkins University Press, 1992.

Mtshiselwa, Ndikho. "The Age of Reinvented Empire(s) in Africa in the Light of Persian Hegemonic Power: Reading the Books of Deuteronomy and EzraNehemiah in the Context of Zimbabwe." Verbum et Ecclesia 36/1 (2015): 1-9. . "Mind the Working-class People! An African Reading of Leviticus 25:8-55 with Latino/a Critical Tools." Old Testament Essays 29/1 (2016): 133-150.

. "Who Possessed the Promised Land? Scribal Scholarship in the Formation of Patriarchal Narrative(s) and the Holiness Code." Semitica 58/1 (2016): 63-78.

Mutambara, Marcia Victoria. "Xenophobia and Human Security: Gender-based Violence Experiences of Zimbabwean Women Working in the Informal Sector in Durban, KwaZulu-Natal.” PhD Thesis, Pietermaritzburg: University of KwaZulu Natal, 2018.

Na'aman, Nadav. "Dispatching Canaanite Maidservants to the Pharaoh." Ancient Near Eastern Studies 39/1 (2002): 76-82. . "The Exodus Story: Between Historical Memory and Historiographical Composition.” Journal of Ancient Near Eastern Religions 11/1 (2011): 39-69.

Oduyoye, Mercy A. Beads and Strands: Reflections of an African Woman on Christianity in Africa. Maryknoll: Orbis Books, 2002.

Okure, Theresa. "Women in the Bible." Pages 47-59 in With Passion and Compassion: Third World Women Doing Theology. Edited by Virginia Fabella and Mercy A. Oduyoye. Maryknoll: Orbis Press, 1988.

Otto, Eckart. "Mose und das Gesetz: Die Mose-Figur als Gegenentwurf politischer Theologie zur neuassyrischen Königstheologie im 7. Jh. v. Chr.” Pages 51-67 in Mose, Ägypten und das Alten Testament. Edited by Eckart Otto. Stuttgarter Bibelstudien 189. Stuttgart: Katholosiches Bibelwerk, 2000.

Parpola, Simo. The Correspondence of Sargon II: Letter from Assyria and the West. Helsinki: University Press, 1987. . "The Construction of Dur-Šarrukin in the Assyrian Royal Correspondence." Pages 47-77 in Khorsabad, le palais de Sargon II, roi d'Assyrie. Edited by Annie Caubet. Paris: La documentation Française, 1995.

Peberdy, Sally and Jonathan Crush. "Trading Places: Cross-border Traders and the South African Informal Economy." SAMP Migration Policy Series 6. Cape Town: Idasa/SAMP, 1998.

Redford, Donald B. "Observations on the Sojourn of the Bene-Israel." Pages 57-66 in Exodus: The Egyptian Evidence. Edited by Ernest S. Frerichs and Leonard $\mathrm{H}$ Lesko. Winona Lake: Eisenbrauns, 1997.

Römer, Thomas C. 'La construction d'une 'Vie de Moïse' dans la Bible Hébraïque et chez quelques auteurs Héllenistiques.” Transversalités 85 (2003): 13-30. 
Rugwiji, Temba. “Appropriating Judean Post-Exilic Literature in a Postcolonial Discourse: A Case for Zimbabwe." PhD thesis, University of South Africa, 2013.

Schmid, Konrad. Genesis and the Moses Story: Israel's Dual Origins in the Hebrew Bible. Winona Lake: Esenbrauns, 2010.

Segovia, Fernando F. "Pedagogical Discourse and Practices in Cultural Studies: Towards a Contextual Biblical Pedagogy." Pages 118-136 in Teaching the Bible: The Discourse and Politics of Biblical Pedagogy. Edited by Fernando F. Segovia and Mary Ann Tolbert. Maryknoll: Orbis Books, 1998.

Usue, Emmanuel O. "Restoration or Desperation in Ezra and Nehemiah? Implications for Africa." Old Testament Essays 20/3 (2007): 830-847.

Von Kitzing, Nora S. "Gender-based Violence on Vulnerable Migrant Women in Periurban Johannesburg and How They Respond." Research Paper, University of the Witwatersrand, Johannesburg, 2017.

Wisborg, Poul et al. Farm Workers and Farm Dwellers in Limpopo, South Africa: Struggles over Tenure, Livelihoods and Justice. Cape Town: Institute for Poverty, Land and Agrarian Studies, 2013.

Wittenberg, Gunther H. “Old Testament Theology: For Whom?” Semeia 73 (1996): 221-240.

Zlotnick-Sivan, Helena. "Moses the Persian? Exodus 2, the 'Other' and Biblical 'Mnemohistory'." Zeitschrift für die Alttestamentliche Wissenschaft 116/2 (2004): 189-205.

Prof VNN Mtshiselwa, Department of Biblical and Ancient Studies, University of South Africa, email: mtshivnn@unisa.ac.za, ORCID: https://orcid.org/00000002-2111-4563 